\title{
Implementasi Pembelajaran Kooperatif Tipe TAI (Team Assisted Individualization) untuk Meningkatkan Aktivitas dan Hasil Belajar Fisika Siswa SMP Negeri 3 Bolo Tahun Pelajaran 2018/2019
}

\author{
Komala Sari \\ SMP Negeri 3 Bolo, Bima, Indonesia \\ *Coresponding Author: komalasari91@ gmail.com
}

\begin{abstract}
Abstrak: Penelitian ini bertujuan untuk mengetahui pengaruh penerapan model pembelajran koperatif tipe TAI (Team assisted individualization) terhadap pembelajran di kelas. Jenis penelitian ini adalah penelitian tindakan kelas ynag dilaksanakan dalam dua siklus dan masingmasing siklus terdiri dari perencanaan, pelaksanaan tindakan, observasi, evaluasi, dan refleksi. Ada dua jenis data ynag digunakan yaitu data kualititatif ynag berupa lembar observasi dan data kuantitatif ynag berupa hasil test. Untuk analisis data digunakan pedoman ketuntasan belajar dimana siswa dikatakan tuntas secara klasikal $85 \%$ atau lebih dan secara individual apabila memperoleh nilai $\geq 60$ sesuai dengn kurikulum. Hasil penelitian menunjukan adanya peningkatan hasil belajar siswa. Dari siklus I dan II, dimana padaa siklus I rata-rata hasil belajar siswa 63,80 dengn ketuntasan klasikal 71\% kemudian padaa siklus II rata-rata hasil belajar siswa 70,17 dengn ketuntasan klasikal 89\%. Sedangkan aktivitas siswa siklus I adalah 2,35 sehingga dapat digolongkan kurang aktif dan siklus II adalah 2,85 tergolong aktif. Maka dapat disimpulkan bhwa dengn menerapkan model pembelajran koperatif tipe TAI (Team Assisted Indulization) dapat meningkatkan aktivitas dan hasil belajar fisika materi gerak lurus padaa siswa kelas VIIA semester II di SMP Negeri 3 Bolo Tahun Pelajaran 2018/2019.
\end{abstract}

Kata Kunci: Pembelajaran Kooperatif tipe TAI; aktivitas dan hasil belajar.

\section{PENDAHULUAN}

Dalam kehidupan sosial kemanusiaan, pendidikan merupakan upaya ynag melahirkan proses pembelajran dengn tujuan membawa manusia menjadi sosok ynag profesional secara intelektual melalui proses transfer of knowlwdge atau transfer ilmu pengetahuan. Selain itu juga pendidikan merupakan proses ynag bermuara padaa upaya pembentukan masyarakat ynag berwatak, beretika dan berestetika melalui transfer of value ynag terkandung di dalamnya. Pendidikan merupakan proses mengubah tingkah laku manusia, dalam arti ynag luas termasuk pola pikir, merasakan, dan tindakan secara terbuka. Pandangan ini jelas bhwa tujuan pendidkan adalah melakukan perubahan perilaku ynag ditentukan oleh lembaga pendidikan.

Sekolah merupakan lembaga ynag dipercaya masyarakat sebagai tempat untuk menuntut ilmu. Seseorang ynag pernah duduk di bangku sekolah akan memiliki wawasan, pengetahuan bahkan kepribadian ynag lebih dari ynag lainnya. Oleh karena itu orang tua ynag menyekolahkan anaknya berharap anaknya kelak memiliki nilai lebih dari orang lain di sekitarnya sehingga dapat dibanggakan. Begitu besar tanggung jawab sekolah sebagai lembaga pendidikan formal maka lembaga ini dituntut untuk maksimalkan kegiatan pembelajran ynag ada di dalamnya. Karena sekolah merupakan lembaga pendidikan, maka di dalamnya terdapat proses belajar mengajar. Belajar dilakukan oleh siswa sedangkan mengajar dilkukan oleh guru. Dari kegiatan inilah maka terjadi proses transfer ilmu dari guru ke siswa.

Dalam setiap kegiatan selalu ada tujuan ynag ingin dicapai. Begitu juga dengn suatu pembelajran ynag merupakan bagian dari pendidikan ada tujuan ynag ingin dicapai. Adapun tujuan ynag ingin dicapai dalam proses pebelajaran adalah hasil 
belajar siswa didik. Hasil belajar ini tergantung padaa proses pembelajran, yaitu bagaimana menggerakkan semua potensi ynag dimilki siswa. Dari sekian unsur ynag sangat menentukan kualitas pembelajran adalah metode ynag digunakan guru dalam menyampaikan materi pelajaran.

Hal ini dapat dilihat dari rendahnya nilai rata-rata prestasi belajar fisika siswa yakni padaa semester satu tahun pelajaran 2017/2018. Data selengkapnya dapat dilihat padaa tabel berikut.

Tabel 1. Nilai rata-rata Fisika siswa kelas VII SMP Negeri 3 Bolo Tahun Pelajaran 2017/2018.

\begin{tabular}{|c|c|c|c|}
\hline No & Kelas & $\begin{array}{c}\text { Nilai rata-rata mata } \\
\text { pelajaran Fisika }\end{array}$ & KKM \\
\hline 1 & VII A & 61 & 60 \\
\hline 2 & VII B & 60 & 60 \\
\hline 3 & VII C & 63 & 60 \\
\hline 4 & VII D & 63 & 60 \\
\hline
\end{tabular}

Tabel 2. Nilai rata-rata Fisika siswa kelas VII SMP Negeri 3 Bolo Tahun Pelajaran 2017/2018.

\begin{tabular}{|c|c|c|c|}
\hline No & Kelas & $\begin{array}{c}\text { Nilai rata-rata mata } \\
\text { pelajaran Fisika }\end{array}$ & KKM \\
\hline 1 & VII A & 58 & 60 \\
\hline 2 & VII B & 60 & 60 \\
\hline 3 & VII C & 63 & 60 \\
\hline 4 & VII D & 65 & 60 \\
\hline
\end{tabular}

Sebenarnya di SMP Negeri 3 Bolo sudah mempunyai alat peraga untuk praktikum tetapi penggunaannya belum maksimal karena belum mempunyai ruangan khusus untuk praktikum. Alat peraga ini juga mendukung proses pembelajran sebagai media pendukung untuk menjelaskan materi pelajaran supaya siswa mudah memahami materi pelajaran ynag dipelajari. Dalam proses pembelajran fisika di SMP Negeri 3 Bolo masih sering menggunakan pola lama dimana kegiatan pembelajran didominasi oleh guru untuk memberikan informasi kepadaa siswa. Metode pembelajran ynag sering digunakan adalah metode ceramah, mencatat dan sebagainya meskipun kadang juga diterapkan metode praktikum atau demonstrasi, tetapi ynag lebih sering digunakan adalah metode ceramah dan mencatat.

Dalam upaya memenuhi tuntutan dan mengatasi masalah tersebut, maka diperlukan metode pembelajran ynag diharapkan mampu melibatkan siswa untuk aktif dalam proses pembelajran tersebut. Metode adalah suatu cara ynag digunakan untuk mencapai tujuan ynag telah ditetapkan Ada banyak model pembelajran ynag mampu mengaktifkan siswa dalam proses pembelajran. Salah satunya adalah model pembelajran cooperative (kelompok). Salah satu macam dari model cooperative (kelompok) ini adalah tipe TAI (Team Assisted Individualization). Model ini merupakan kolaborasi antara belajar individu dengn belajar kelompok. Diharapkan dengn diterapkan model pembelajran Cooperative tipe TAI (Team Assisted Individualization) ini siswa dapat aktif dalam mengikuti pembelajran Fisika di kelas.

Dalam uraian di atas, maka dalam penelitian ini akan diteliti mengenai masalah tersebut yaitu implementasi model pembelajran cooperative tipe TAI (team assisted 
individualization) untuk meningkatkan aktivitas dan hasil belajar fisika siswa kelas VII SMP Negeri 3 Bolo tahun pelajaran 2018/2019.

\section{KAJIAN TEORI}

\section{Pembelajran Koperatif}

Pembelajran koperatif adalah konsep ynag lebih luas meliputi semua jenis kerja kelompok termasuk bentuk-bentuk ynag lebih dipimpin oleh guru atau diarahkan oleh guru. Secara umum pembelajran koperatif dianggap lebih diarahkan oleh guru, dimana guru menetapkan tugas dan pertanyaan-pertanyaan serta menyediakan bahanbahan dan informasi ynag dirancang untuk membantu peserta didik menyelesaikan masalah ynag dimaksud.

Istilah Cooperative learning dalam pengertian bahasa Indonesia dikenal dengn nama pembelajran koperatif. oleh guru. Menurut Johnson \& Johnson dalam Isjoni, (1994) cooperative adalah mengelompokkan siswa didalam kelas kedalam suatu kelompok kecil agar siswa dapat bekerja sama dengn kemampuan maksimal ynag mereka miliki dan mempelajari satu sama lain dalam kelompok tersebut.

Menurut Slavin dalam Isjoni (2010), pembelajran koperatif adalah suatu model pembelajran dimana siswa belajar dan bekerja dalam kelompok-kelompok kecil antara kolaboratif ynag anggotanya 4-6 orang dengn struktur kelompok heterogen.

Padaa dasarnya model pembelajran koperatif sikembangkan untuk mencapai setidak-tidaknya tiga tujuan penting ynag dirangkum Ibrahim, et al dalam Isjoni. (2010)

Dalam pembelajran koperatif meskipun mencangkup beragam tujuan social, juga memperbaiki prestasi siswa atau tugas-tugas akademis penting lainnya. Beberapa ahli berpendapat bhwa model ini unggul dalam membantu siswa memahami konsepsulit. Para pengembang model ini menunjukan, model struktur penghargaan koperatif telah dapat meningkatkan nilai siswa padaa belajar akademik dan perubahan norma ynag berhubungan dengn hasil belajar.

Tujuan model pembelajran kooperatf adalah penerimaan secara luas dari orang-orang ynag berbeda berdasarkan ras, budaya, kelas social, kemampuan, dan ketidakmampuannya. Pembelajran koperatif member peluang bagi siswa dari berbagai latar belakang dan kondisi untuk bekerja dengn saling bergantung padaa tugas-tugas akademik dan melalui struktur penghargaan koperatif akan belajar saling menghargai satu sama lain.

Tujuan penting ketiga pembelajran koperatif adalah mengajarkan kepadaa siswa keterampilan bekerjasama dan kolaborasi. Keterampilan ini amat penting untuk dimiliki oleh para siswa sebagai warga masyarakat, bangsa dan Negara, karna mengingat kenyataan ynag dihadapi bangsa ini dalam mengatasi masalah-masalah social ynag semakin kompleks, serta tantangan bagi peserta didik supaya mampu dalam menghadapi persaingan global untuk memenangkan persaingan tersebut.

\section{Pembelajran Koperatif Tipe TAI (Team Assisted Individualization)}

Ada beberapa macam tipe di dalam model pembelajran Cooperatif salah satunya adalah tipe TAI (Team Assisted Individualization), Model ini dikembangkan oleh Slavin. Tipe ini mengkombinasikan keunggulan pembelajran kelompok dan 
pembelajran individu. Tipe ini dirancang untuk mengatasi kesulitan belajar siswa secara individual. Oleh karena itu kegiatan pembelajrannya lebih banyak digunakan untuk pemecahan masalah. Ciri khas dari model pembealajaran tipe ini yaitu terlebih dahulu siswa belajar materi pelajaran secara individu kemudian hasil dari belajar individu dibawa ke kelompok-kelompok untuk didiskusikan dan saling dibahas oleh anggota kelompok dan semua anggota kelompok bertanggung jawab atas keseluruhan jawaban sebagai tanggung jawab bersama.

TAI dirancang untuk memuaskan kriteria berikut ini untuk menyelesaikan masalah-masalah berikut teoritis dan praktis dari sistem pengajaran individual :

- Dapat meminimalisir keterlibatan guru dalam memeriksa dan pengelolaan rutin

- Guru setidaknya akan menghabiskan separuh dari waktunya untuk mengajar kelompok-kelpmpok kecil.

- Operasional program tarsebut akan sedemikian sederhananya sehingga para siswa di kelas dapat melakukannya.

- Para siswa akan termotivasi untuk mempelajari materi ynag diberikan dengn cepat dan akurat, dan tidak akan bisa berbuat curang atau menemukan jalan pintas.

- Tersedianya banyak cara pengecekan penguasaan supaya para siswa jarang menghabiskan waktu mempelajari kembali materi ynag sudah mereka kuasai atau menghadapi kesulitan serius ynag membutuhkan bantuan guru.

- Para siswa akan dapat melakukan pengecekan satu sama lain, sekalipun bila siswa ynag mengecek kemampuannya ada di bawah siswa ynag dicek dalam rangkaian pengajaran.

- Programnya mudah dipelajari baik oleh guru maupun siswa.

Program TAI ynag telah dikembangkan untuk memenuhi semua kriteria ini dipandu dalam satu kelas, mendapat revisi intensif, dikaji dalam dua sekala penuh tetapi singkat (delapan dan sepuluh minggu, secara berturut-turut), eksperimen di lapangan (Slavin, Leavey, dan Madden, 1984), direvisi lagi, dan selanjutnya dievaluasi dengn sukses dalam tiga skala besar eksperimen di lapangan. Program seperti ynag sekarang ini hadir digambarkan dalam bagian-bagian berikut ini.

Teams. Para siswa dalam TAI dibagi ke dalam tim-tim ynag beranggotakan 4 sampai 5 orang.

Tes Penempatan. Para siswa dberikan tes pra-program dalam bidang operasi fisika padaa permulaan pelaksanan program.

Materi-materi Kurikulum. Untuk sebagian besar dari pengajaran fisika, para siswa bekerja padaa materi-materi kurikulum individual,

Belajar Kelompok. Langkah berikutnya ynag mengikuti tes penempatan adalah guru mengajar pelajaran pertama. Selanjutnya para siswa diberikan tempat untuk memulai dalam unit fisika individual. Unit tersebut tertera dalam bukubuku siswa.

Para siswa mengerjakan unit-unit mereka dalam kelompok mereka, mengikuti langkah-langkah sebagai berikut :

1. Para siswa membentuk kelompok ynag terdiri dari 2 atau 3 orang dalam tim mereka untuk melakukan pengecekan.

2. Para siswa membaca halaman panduan mereka dan meminta teman satu tim atau guru untuk membantu bila diperlukan. 
3. Tiap siswa mengerjakan empat soal pertama dalam latihan kemampuannya sendiri dan selanjutnya jawabannya dicek oleh teman satu timnya dengn halaman jawaban ynag sudah tersedia, ynag dicetak dengn urutan terbalik di dalam buku.

4. Apabila siswa sudah dapat menyelesaikan keempat soal dengn benar dalam latihan kemampuan terakhir, dia akan mengerjakan tes formatif $\mathrm{A}$, yaitu kuis ynag terdiri dari sepuluh soal ynag mirip dengn latihan kemampuan terakhir.

5. Tes formatif para siswa ditandatangani oleh siswa pemeriksa ynag beasal dari tim lain supaya bisa mendapatkan tes unit ynag sesuai.

Skor Tim dan Rekognisi Tim. Padaa tiap akhir minggu, guru menghitung jumlah skor tim. Skor ini didasarkan padaa jumlah rata-rata unit ynag bisa dicakupi oleh tiap anggota tim dan jumlah tes-tes unit ynag berhasil diselesaikan dengn akurat.

Kelompok Pengajaran. Setiap hari guru memberikan pengajaran selama sekitar sepuluh sampai lima belas menit kepadaa dua atau tiga kelompok kecil siswa ynag terdiri dari siswa-siswa dari tim berbeda ynag tingkat pencapaian kurikulumnya sama.

Tes Fakta. Seminggu dua kali, para siswa diminta mengerjakan tes-tes fakta selama tiga menit. Para siswa tersebut dierikan lembar-lembar fakta untuk dipelajari di rumah untuk persiapan menghadapi tes-tes ini.

Tes Seluruh Kelas. Padaa akhir tiap tiga minggu, guru menghentikan program individual dan menghabiskan satu minggu mengajari seluruh kelas.

\section{Aktivitas Belajar}

Belajar bukanlah berproses dalam kehampaan. Tidak pula pernah sepi dari berbagai aktivitas. Tidak pernah liat orang belajar tanpa melibatkan aktivitas raganya. Apalagi bila aktivitas belajar itu berhubungan dengn masalah belajar menulis, mencatat, memandang, membaca, mengingat, berpikir, latihan atau praktik, dan sebagainya.

Dalam belajar, seseorang tidak akan dapat menghindarkan diri dari suatu situasi. Situasi akan menentukan aktivitas apa ynag akan dilakukan dalam rangka belajar.

\section{Hasil Belajar Siswa}

Menurut Suprijono (2010) Hasil belajar adalah pola-pola perbuatan, nilai-nilai, pengertian-pengertian, sikap-sikap, apresiasi, dan keterampilan. Merujuk pemikiran Gagne, hasil belajar berupa:

1. Informasi verbal yaitu kapabalitas mengungkapkan pengetahuan dalam bentuk bahasa, baik lisan maupun tertulis.

2. Keterampilan intelektual yaitu kemampuan mempresentasikan konsep dan lambang.

3. Strategi kognitif yaitu kecakapan menyalurkan dan mengarahkan aktivitas kognitifnya sendiri. Kemampuan ini meliputi penggunaan konsep dan kaidah dalam memecahkan masalah.

4. Keterampilan motorik yaitu kemampuan melakukan serangkaian gerak jasmani dalam urusan dan koordinasi, sehingga terwujud otomatisme gerak jasmani.

5. Sikap adalah kemampuan menerima atau menolak objek berdasarkan penilaian terhadap objek tersebut. Sikap berupa kemampuan menginternalisasi dan 
eksternalisasi nilai-nilai. Sikap merupakan kemampuan menjadikan nilai-nilai sebagai standar perilaku.

Berdasarkan pengertian di atas maka dapat disimpulkan bhwa hasil belajar adalah suatu penilaian akhir dari proses pembelajran ditandai perubahan perilaku secara keseluruhan tidak hanya padaa satu aspek potensi kemanusiaan saja karena turut serta dalam membentuk kepribadian seseorang.

Pembelajran koperatif menekankan padaa kelompok kecil ynag memiliki tingkat kemampuan ynag berbeda dan saling bekerja sama sedangkan tipe TAI merupakan belajar ynag mengkombinasikan belajar koperatif dengn belajar individu sehingga pembelajran koperatif tipe TAI akan lebih mengoptimalkan hasil proses belajar mengajar. Sesuai hasil observasi di lapangan berupa wawancara dengn guru sejauh ini di SMP Negeri 3 Bolo masih menggunakan metode ceramah, selain itu menurut siswa metode ceramah ynag dipakai selama selama ini hanya bersumber dari satu arah dan bersifat menerima tanpa adanya timbal balik antara guru dan siswa.

Cakupan materi ynag dipelajari dengn adanya aktivitas siswa ynag efektif baik secara individu maupun klasikal, maka diduga salah satu ynag dapat memberikan efektivitas ynag besar terhadap penguasaan materi ynag akan mempengaruhi peningkatan hasil belajar siswa adalah dengn penerapan model pembelajran koperatif tipe TAI akan meningkatkan hasil belajar padaa mata pelajaran fisika.

\section{METODE PENELITIAN}

\section{Jenis Penelitian}

Jenis penelitian ynag digunakan adalah penelitian tindakan kelas (PTK) ynag dilakukan padaa kelas VII SMP Negeri 3 Bolo. Menurut Arikunto (2007), penelitian tindakan kelas merupakan suatu pencermatan terhadap kegiatan belajar dan dalam sebuah tindakan, ynag sengaja dimunculkan dan terjadi dalam sebuah tindakan, ynag terjadi dalam sebuah kelas secara bersama. Jadi dalam sebuah kelas secara bersama. Jadi dalam penelitian ini menggunakan penelitian tindakan kelas (PTK) ynag tujuannya untuk mengetahui peningkatan aktivitas pembelajran dibandingkan dengn pendekatan ynag lain terhadap aktivitas dan peningkatan hasil belajar fisika siswa kelas VII (tujuh ) SMP Negeri 3 Bolo.

\section{Pendekatan Penelitian}

Dalam penelitian ini pendekatan ynag di gunakan terbagi dalam dua jenis pendekatan yaitu kualitatif dan kuantitatif. Dalam tindak kelas (PTK) pendekatan kuantitatif di gunakan untuk mencari data hasil evaluasi belajar siswa, sedangkan pendekatan kualitatif digunakan untuk mencatat data hasil observasi. Menurut Sugiono, (2004) pendekatan kualitatif adalah jenis data ynag di nyatakan dalam bentuk kata, kalimat dan gambar.Pendekatan kuantitatif adalah jenis data ynag berbentuk angka, atau data kualitatif ynag diangkakan.

\section{Rancangan Penelitian}

Penelitian tindakan kelas ini direncanakan pelaksanaannya dalam tiga siklus, setiap siklus dilaksanakan sesuai dengn skenario pembelajran ynag telah dibuat dan terdiri dari empat tahap kegiatan yaitu: tahap perencanaan, tahap pelaksanaan tindakan, tahap observasi serta evaluasi dan refleksi. 


\section{Subjek Penelitian}

Subjek merupakan sekumpulan dari kelompok-kelompok siswa ynag memiliki peluang sama untuk dijadikan objek penelitian. Subjek penelitian ynag diambil dalam penelitian ini adalah siswa kelas VII SMP Negeri 3 Bolo Tahun Pelajaran 2018/2019.

\section{Teknik Pengumpulan Data}

Data ynag dikumpulkan berupa data observasi aktivitas guru dan siswa dan data tes hasil belajar siswa.

1. Observasi

Observasi adalah suatu cara untuk mengadakan penilaian dengn jalan mengadakan pengamatan secara langsung dan sistematis. Data-data ynag diperoleh dalam observasi itu dicatat dalam suatu catatan observasi. Kegiatan pencatatan dalam hal ini adalah bagian dari pengamatan.

Kegiatan observasi ini dilakukan secara kontinyu setiap pembelajran berlangsung dalam pelaksanaan tindakan dengn mengamati aktivitas siswa dan kemampuan guru dalam mengelola KBM.

2. Tes

Metode tes adalah suatu cara untuk mengadakan penilaian ynag berbentuk suatu tugas atau serangkaian tugas ynag harus diselesaikan oleh anak atau sekelompok anak sehingga menghasilkan suatu nilai tentang kemampuan siswa dalam mengkomunikasikan materi ynag telah dibahas dan prestasi anak sehinga menghasilkan suatu nilai tentng kemampuan siswa dalam mengkomunikasikan materi ynag telah dibahas dan prestasi anak tersebut, dapat dibandingkan dengn nilai ynag dicapai oleh anak-anak lain atau nilai standar ynag diterapkan.

Siswa akan diberikan tes hasil belajar ynag diadakan secara individual dengn tujuan untuk mengetahui peningkatan prestasi siswa padaa setiap perlakuan dengn tujuan untuk membadingkan aktivitas dan hasil belajar siswa.

\section{Instrumen Penelitian}

Untuk mendapat data ynag diperoleh dalam penelitian ini dibutuhkan instrumen penelitian, ynag dimaksud dengn instrumen penelitian adalah alat padaa waktu penelitian ynag menggunakan metode (Arikunto, 2006).

Adapun instrumen ynag digunakan dalam penelitian berupa:

1. Lembar Observasi

Penggunaan lembar observasi dalam penelitian ini yaitu untuk mengetahui aktivitas siswa padaa saat proses belajar mengajar berlangsung dengn menggunakan model pembelajran tipe TAI dan kemampuan guru dalam mengelola KBM.

2. Soal Tes

Tes ynag digunakan dalam pemelitian ini untuk mengukur data mengenai prestasi atau hasil belajar siswa. Tes ini berisikan soal-soal ynag berkaitan dengn materi ynag diajarkan dan materi tugas. Dalam penelitian ini tes ynag digunakan adalah tes pilihan ganda soal-soal ini diambil dari buku paket fisika ataupun refrensi ynag relevan. Instrumen ynag disusun oleh peneliti ynag disetujui oleh guru mata pelajaran dengn pedoman padaa kurikulum ynag berlaku sekarang ini. 


\section{Teknik Analisis Data}

1. Data Hasil Observasi Siswa

Dari hasil observasi mengenai aktivitas belajar siswa dinyatakan dalam bentuk persentase ynag dapat dianalisis dengn cara:

$$
\% \text { aktivitas belajar }=\frac{\text { jumlah total skor ynag diperoleh }}{\text { jumlah skor maksimal indikator }} \times 100
$$

Untuk mengetahui tinggi rendahnya aktivitas belajar siswa dengn menggunakan model pembelajran tipe TAI dalam strategi belajarnya dapat ditentukan lewat interval persentase sebagai berikut

Tabel 3. Interval porsentase Hasil Observasi Siswa

\begin{tabular}{|c|c|c|}
\hline No & Persentase & Kategori \\
\hline 1. & $76 \%-100 \%$ & Sangat tinggi \\
\hline 2. & $56 \%-75 \%$ & Tinggi \\
\hline 3. & $41 \%-55 \%$ & Cukup tinggi \\
\hline 4. & $20 \%-40 \%$ & Kurang tinggi \\
\hline 5. & Kurang dari $20 \%$ & Sangat kurang \\
\hline
\end{tabular}

2. Data Hasil Tes

Setelah memperoleh data tes hasil belajar siswa selanjutnya dicari ketuntasan belajar siswa, kemudian dianalisis dengn secara kuantitatif. Untuk mengetahui ketuntasan siswa digunakan kriteria sebagai berikut :

Ketuntasan individu setiap siswa dalam proses belajar mengajar dikatakan tuntas secara individu apabila siswa mampu memperoleh nilai 60, sebagai standar ketuntasan belajar minimal ynag telah ditetapkan oleh sekolah tempat peneliti melakukan penelitian.

3. Ketuntasan klasikal dihitung dengn persamaan

$$
\mathrm{KK}=\frac{\mathrm{K}}{\mathrm{Z}} \times 100 \%
$$

Keterangan:

$\mathrm{KK} \quad=$ Ketuntasan klasikal

$\mathrm{X}=$ Jumlah siswa ynag memperoleh nilai ? 61

$\mathrm{Z} \quad=$ Jumlah siswa ynag ikut tes

Sesuai dengn petunjuk penelitian diatas, kelas dapat dinyatakan tuntas klasikal apabila ketuntasan klasikal mencapai 85\%. Analisis kuantitatif dilakukan dengn membandingkan ketuntasan ynag dicapai padaa tiap-tiap siklus yaitu siklus I dan II.

4. Data hasil aktivitas guru dan siswa

\section{a. Data aktivitas siswa}

Data aktivitas belajar siswa dianalisis dengn cara sebagai berikut :

1. Menentukan skor ynag diperoleh

- . Skor 4 diberikan jika 3 deskriptor nampak

- . Skor 3 diberikan jika 2 deskriptor nampak

- . Skor 2 diberikan jika 1 deskriptor nampak

- . Skor 1 diberikan jika tidak ada deskriptor nampak 
2. Menentukan MI dan SDI

$\mathrm{Mi}=\frac{1}{2}($ skor tertinggi + skor terendah $)$

$\mathrm{SDi}=\frac{1}{3} \mathrm{Mi}$

Keterangan :

$\mathrm{Mi}=$ Mean ideal

SDi $=$ Standar deviasi ideal

Tabel 4. Kriteria Untuk Aktivitas Belajar Siswa

\begin{tabular}{|c|c|}
\hline Interval & Kategori \\
\hline $\mathrm{AS} \geq\left(\mathrm{M}_{i}+0,5 \mathrm{SD}_{i}\right)$ & Sangat aktif \\
$\mathrm{M}_{i}+0,5 \mathrm{SD}_{i} \leq \mathrm{AS}<\mathrm{M}_{i}+0,5 \mathrm{SD}_{i}$ & Aktif \\
$\mathrm{M}_{i}-1,5 \mathrm{SD}_{i} \leq \mathrm{AS}<\mathrm{M}_{i}+0,5 \mathrm{SD}_{i}$ & Cukup aktif \\
$\mathrm{M}_{i}-0,5 \mathrm{SD}_{i} \leq \mathrm{AS}<\mathrm{M}_{i}-0,5 \mathrm{SD}_{i}$ & Kurang aktif \\
$\mathrm{AS}<\left(\mathrm{M}_{i}-1,5 \mathrm{SD}_{i}\right)$ & Sangat kurang aktif \\
\hline
\end{tabular}

Keterangan : AS $=$ Aktifitas Siswa

\section{a. Data aktivitas guru} sebagai berikut :

Data aktivitas guru selama pembelajran berlangsung cara

1. Menentukan skor ynag diperoleh

- Skor 4 diberikan jika 3 deskriptor nampak

- Skor 3 diberikan jika 2 deskriptor nampak

- Skor 2 diberikan jika 1 deskriptor nampak

- Skor 1 diberikan jika tidak ada deskriptor nampak

2. Menentukan MI dan SDI

$$
\begin{aligned}
& \mathrm{Mi}=\frac{1}{2} \text { (skor tertinggi }+ \text { skor terendah } \\
& \mathrm{SDi}=\frac{1}{3} \mathrm{Mi}
\end{aligned}
$$

Keterangan :

Mi = Mean ideal

SDi $=$ Standar deviasi ideal

Tabel 5. Kriteria Untuk Aktivitas Mengajar Guru

\begin{tabular}{|c|c|}
\hline Interval & Kategori \\
\hline $\mathrm{AG} \geq\left(\mathrm{M}_{i}+0,5 \mathrm{SD}_{i}\right)$ & Sangat aktif \\
$\mathrm{M}_{i}+0,5 \mathrm{SD}_{i} \leq \mathrm{AG}<\mathrm{M}_{i}+0,5 \mathrm{SD}_{i}$ & Aktif \\
$\mathrm{M}_{i}-0,5 \mathrm{SD}_{i} \leq \mathrm{AG}<\mathrm{M}_{i}+0,5 \mathrm{SD}_{i}$ & Cukup aktif \\
$\mathrm{M}_{i}-1,5 \mathrm{SD}_{i} \leq \mathrm{AG}<\mathrm{M}_{i}-0,5 \mathrm{SD}_{i}$ & Kurang aktif \\
$\mathrm{AG}<\left(\mathrm{M}_{i}-1,5 \mathrm{SD}_{i}\right)$ & Sangat kurang aktif \\
\hline Keterangan : $\mathrm{AG}=$ Aktifitas Guru & (Adhar, 2009)
\end{tabular}




\section{HASIL DAN PEMBAHASAN}

\section{Hasil Penelitian}

Penelitian tindakan kelas ini dilakukan untuk mengetahui aktivitas dan hasil belajar siswa padaa pokok bahasan Gerak Lurus di SMP Negeri 3 Bolo dengn penerapan model pembelajran koperatif tipe TAI. Dari hasil evaluasi dan hasil observasi diperoleh data kualitatif dan data kuantitatif, data kualitatif tentang aktivitas siswa dan aktivitas guru ynag akan memberikan gambaran tentang kegiatan siswa dan guru selama proses belajar mengajar berlangsung dan data kuantitatif tentang hasil belajar siswa secara klasikal. Penelitian ynag dilakukan selama satu bulan ynag dimulai dari tanggal 29 April 2011 sampai dengn tanggal 3 Juni 2011, telah memberikan hasil ynag diinginkan peneliti. Tahap-tahap dalam proses penerapan metode tipe TAI baik padaa siklus I maupun padaa siklus II dilaksanakan sesuai dengn RPP ynag telah disusun.

Adapun hasil penelitian ini akan dikemukakan analisis data diperoleh dari hasil tes evaluasi dan hasil observasi padaa setiap siklus ynag telah direncanakan. Data ynag diperoleh berupa data kuantitatif dari hasil tes evaluasi dan data kualitatif dari hasil observasi. Data kuantitatif ynag diperoleh dari hasil tes evaluasi akan memberikan jawaban mengenai berhasil atau tidaknya proses pembelajran padaa pokok bahasan gerak Lurus melalui penerapan model pembelajran tipe TAI. Data ynag memberikan gambaran tentang aktivitas guru dan siswa terhadap proses pembelajran.

\section{Deskripsi Hasil Instrumen Penelitian}

\section{Hasil Observasi Aktivitas Guru Dan Siswa}

Data Hasil Observasi Aktivitas Guru

Padaa kegiatan pembelajran padaa siklus I dan siklus II segala aktivitas ynag dilakukan oleh guru di dalam kelas dicatat oleh observer padaa lembar observasi. Berikut data hasil observasi aktivitas guru padaa siklus I dan siklus II.

Tabel 6. Data hasil observasi aktivitas guru siklus I dan siklus II

\begin{tabular}{|l|c|c|c|c|c|}
\hline No & Siklus & $\begin{array}{c}\text { Aspek ynag } \\
\text { di amati }\end{array}$ & $\begin{array}{c}\text { Skor } \\
\text { total }\end{array}$ & $\begin{array}{c}\text { Rata-rata } \\
\text { skor }\end{array}$ & Kategori \\
\hline 1 & I & 17 & 34 & 2 & Aktif \\
\hline 2 & II & 17 & 37 & 2,17 & Aktif \\
\hline
\end{tabular}

Hasil observasi aktivitas guru ynag terdapat padaa tabel 4.4 di atas menunjukan bhwa aktivitas guru padaa siklus I dan siklus II berkategori aktif.

\section{Data Hasil Observasi Aktivitas Siswa}

Sedangkan hasil observasi aktivitas siswa padaa siklus I dan siklus II diperoleh data sebagai berikut:

Tabel 7. Data hasil observasi aktivitas siswa siklus I dan siklus II

\begin{tabular}{|l|c|c|c|c|c|}
\hline No & Siklus & Banyak siswa & Skor total & Rata-rata & Kategori \\
\hline 1 & I & 28 & 33 & 2,35 & Kurang Aktif \\
\hline 2 & II & 28 & 40 & 2,85 & Aktif \\
\hline
\end{tabular}


Hasil observasi aktivitas siswa ynag terdapat padaa tabel 4.5 di atas menunjukan bhwa aktivitas siswa siklus I berkatagori kurang aktif sedangkan padaa siklus II berkategori aktif. Sehingga bisa dikatakan bhwa terjadi peningkatan aktivitas siswa dari siklus sebelumnya (lihat lampiran 19 dan 25). Dari hasil observasi kegiatan belajar mengajar, aktivitas guru dan siswa ynag kurang padaa siklus I dapat ditingkatkan padaa siklus II.

\section{Data Hasil Evaluasi}

Setelah pembelajran padaa siklus I dan siklus II selesai, guru mengadakan evaluasi, Evaluasi dilakukan dengn memberikan tes dalam bentuk soal pilihan ganda sebanyak 20 soal dan alokasi waktu 45 menit (1 jam pelajaran).

Setelah menganalisis hasil evaluasi padaa siklus I dan siklus II diperoleh hasil seperti padaa tabel 8 berikut.

Tabel 8. hasil analisis evaluasi siswa siklus I dan siklus II

\begin{tabular}{|c|c|c|c|c|c|c|c|c|}
\hline \multirow[t]{2}{*}{ No } & \multirow[t]{2}{*}{ Siklus } & \multirow{2}{*}{$\begin{array}{c}\text { Jumlah } \\
\text { Siswa }\end{array}$} & \multicolumn{2}{|c|}{ Jumlah Siswa } & \multirow{2}{*}{$\begin{array}{c}\text { Nilai } \\
\text { Rata-rata }\end{array}$} & \multicolumn{2}{|c|}{ Nilai } & \multirow{2}{*}{$\begin{array}{c}\% \\
\text { Ketuntasan } \\
\text { Klasikal }\end{array}$} \\
\hline & & & Tuntas & $\begin{array}{c}\text { Tidak } \\
\text { Tuntas }\end{array}$ & & Max & Min & \\
\hline 1 & I & 28 & 20 & 8 & 63,80 & 90 & 40 & $71 \%$ \\
\hline 2 & II & 28 & 25 & 3 & 70,17 & 90 & 50 & $89 \%$ \\
\hline
\end{tabular}

Data hasil evaluasi padaa siklus I diperoleh persentase ketuntasan klasikal sebesar $71 \%$ sedangkan padaa siklus II sudah mencapai standar ynag ditentukan yaitu persentase ketuntasan klasikal sebesar 89\%. Berdasarkan hasil tersebut ditetapkan bhwa tujuan pembelajran tindakan kelas siklus II sudah tercapai. Oleh karena itu, tidak perlu lagi mengulangi tindakan, dalam arti tindakan dapat dihentikan.

\section{Pembahasan}

Penelitian ini dilaksanakan sesuai tahapan dalam penelitian tindakan kelas (PTK) dimulai dengn perencanaan, pelaksanaan tindakan, evaluasi dan refleksi. Penelitian tindakan kelas dilakukan dalam dua siklus dengn menggunakan model tipe TAI padaa materi gerak lurus.

Tahap perencanaan padaa siklus I dimulai dengn membuat rencana pelaksanaan pembelajran, lembar observasi untuk mencatat aktivitas siswa dan guru selama pembelajran berlangsung, lembar evaluasi dan merencanakan analisis hasil evaluasi. Penelitian dilanjutkan padaa tahap pelaksanaan tindakan dimana padaa tahap inilah diterapkan model tipe TAI dengn materi ynag dibahas antara lain: pengertian gerak, kedudukan dan perpindahan, kelajuan dan kecepatan, GLB dan GLBB. Selama proses pembelajran berlangsung dilakukan observasi terhadap aktivitas siswa dan guru ynag dicatat padaa lembar observasi. Hasil observasi menunjukan bhwa skor rata-rata aktivitas siswa siklus I sebesar 2,35 dengn katagori kurang aktif dan skor aktivitas guru sebesar 34 dengn kategori aktif.

Untuk mengetahui keberhasilan proses pembelajran ynag telah dilakukan padaa siklus I diadakan dengn memberikan tes dalam bentuk soal pilihan ganda sebanyak 20 (lampiran 15). Berdasarkan hasil analisis evaluasi hasil belajar dari siklus I diperoleh nilai rata-rata kelas sebesar 63,80 ynag diperoleh dari skor dibagi dengn banyaknya siswa, sedangkan persentase ketuntasan klasikalnya sebesar $71 \%$ 
(lampiran17). Sedangkan padaa siklus II hasil observasi menujukan rata-rata skor aktivitas siswa sebesar 2,85 dengn kategori aktif dan aktivitas guru menujukan skor sebesar 37 dengn kategori aktif. Di akhir pembelajran siklus II diadakan evaluasi dengn memberikan tes dalam bentuk soal pilihan ganda sebanyak 20 soal (lampiran 21). Berdasarkan hasil analisis padaa siklus II diperoleh nilai rata-rata siswa sebesar 70,17 ynag diperoleh dari jumlah skor dibagi banyak siswa, sedangakan persentase ketuntasan klasikal sebesar 89\% (lampiran 23).

Proses belajar mengajar padaa siklus II terlaksana dengn baik dari sebelumnya, hal ini terbukti dengn persentase ketuntasan ynag diperoleh siswa sebesar 89\% dimana dari 28 orang ynag mengikuti evaluasi belajar, ynag tuntas sebanyak 25 orang, sedangkan 3 orang dinyatakan tidak tuntas karena nilai ynag mereka peroleh kurang dari 60. Berdasarkan pengamatan ynag dilakukan bhwa ketidaktuntasan tersebut disebabkan oleh beberapa hal diantaranya, siswa kurang serius memperhatikan saat guru menjelaskan dan padaa saat guru memperbaiki jawaban ynag dianggap sulit oleh siswa, serta kurang semangat dan serius dalam menyelesaikan soal ynag diberikan.

Berdasarkan hasil ynag diperoleh, menunjukan bhwa dengn menerapkan model tipe TAI mampu meningkatkan aktivitas dan hasil belajar fisika siswa padaa materi gerak lurus karena model tipe TAI mengkombinasikan belajar individu dengn belajar kelompok. Sehingga siswa akan menyadari bhwa adanya belajar kelompok dapat memberi kemudahan dalam proses belajar di dalam kelas. Dengn memperhatikan kegiatan pembelajran dan hasil evaluasi ynag diperoleh diketahui bhwa model tipe TAI dapat meningkatkan aktivitas dan hasil belajar fisika siswa kelas VII di SMP Negeri 3 Bolo tahun ajaran 2018/2019.

\section{KESIMPULAN}

Dari hasil penelitian dapat ditarik kesimpulan bhwa: 1) Penerapan model pembelajran koperatif tipe TAI (Team Assisted Individualization) mampu meningkatkan aktivitas belajar siswa kelas VIIA SMP Negeri 3 Bolo. Peningkatan ini dapat dilihat dari perolehan skor rata-rata aktivitas siswa padaa siklus I sebesar 2,35 dengn kategori kurang aktif dan skor rata-rata siswa padaa siklus II sebesar 2,85 dengn kategori aktif; dan b) Penerapan model pembelajran koperatif tipe TAI (team assisted individualization) mampu meningkatkan hasil belajar siswa kelas VIIA SMP Negeri 3 Bolo. Peningkatan ini dapat dilihat dari perolehan nilai rata-rata belajar siswa padaa siklus I sebesar 63,80 atau persentase ketuntasan klaksikal 71\% dan nilai rata-rata siswa padaa siklus II sebesar 70,17 atau persentase ketuntasan klaksikal $89 \%$.

Saran dan tindak lanjut dari hasil penelitian ini adalah: 1) Kepadaa siswa, diharapkan agar dapat belajar dengn bersungguh-sungguh terutama bidang studi fisika, karena sebagai modal dasar untuk belajar físika lebih lanjut; 2) Diharapkan kepadaa guru Fisika SMP Negeri 3 Bolo untuk menerapkan model pembelajran koperatif tipe TAI (Team Assisted Individualization); 3) Kepadaa sekolah, diharapkan dapat mengoptimalkan pembelajran koperatif tipe TAI (Team assisted individualization) sebagai salah satu alternatif model pembelajran; dan 4) Bagi mahasiswa ynag ingin meneliti lebih lanjut diharapkan mencoba menerapkan padaa materi ynag lain dan lebih sempurna. 


\section{DAFTAR PUSTAKA}

Agus Suprijono, 2010, Cooperative Learning Teori Dan Aplikasi PAIKEM, Pustaka Pelajar, Yogyakarta.

Arikunto, S. 2006. Proses Penelitian Suatu Pendekatan Praktik. Jakarta : PT. Rineka Cipta.

Arikunto, S. 2007. Penelitian Tindakan Kelas. Jakarta : PT. Bumi Aksara.

Arikunto, S. 2007. Dasar-Dasar Evaluasi Pendidikan. Jakarta : PT. Rineka Cipta.

Depdikbud, 1994, Kamus Besar Bahasa Indonesia Edisi Kedua, Balai Pustaka, Jakarta.

Hamalik, Oemar. 2009. Proses Belajar Mengajar. Jakarta: Bumi Aksara

Isjoni, Cooperatve Learning, 2010, Alfabeta, Bandung.

Kunandar, 2008,.Langkah Mudah Penelitian Tindakan Kelas Sebagai Pengembangan Profesi Guru, Rajagravindo Persada, Jakarta.

Marten kanginan, 2002, IPA Fisika untuk SMP Kelas VII, Erlangga, Jakarta.

Nana Sudjana, 2009, Dasar-Dasar Proses Belajar Mengajar, Sinar Baru Algesindo, Bandung

Ridwan, 2009, Belajar Mudah Penelitian Untuk Guru-Karyawan Dan Peneliti Semula, Alfabeta, Bandung.

Slavin R E. 1995. Cooperative Learning 2. Ed Boston: Allyn And Bacon

Sugiyono, 2005, Memahami Penelitian Kualitatif, Alfabeta, Bandung

Syaiful Bahri Djamaroh Dan Aswan Zain, 1997, Strategi Belajar Mengajar, Rineka Cipta, Jakarta.

Syarifuddin, S. (2018). Pengaruh Pembelajaran Kooperatif Tipe Jigsaw Dan Tipe Group Investigation (GI) Terhadap Ketercapaian Kompetensi Dan Kemampuan Komunikasi Matematika Siswa Di SMA. Jurnal Ilmiah Mandala Education, 4(1), 163-172

Trianto, 2008, Mndesain Pembelajran Kontekstual (Contextual Teaching And Learning) Di Kelas, Pustaka Publisher, Jakarta. 